THE S. MARK TAPER FOUNDATION

IMPRINT IN JEWISH STUDIES

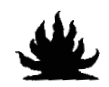

BY THIS ENDOWMENT

THE S. MARK TAPER FOUNDATION SUPPORTS

THE APPRECIATION AND UNDERSTANDING

OF THE RICHNESS AND DIVERSITY OF

JEWISH LIFE AND CULTURE 
The publisher gratefully acknowledges the generous contribution to this book provided by the fewish Studies Endowment Fund of the University of California Press Foundation, which is supported by a major gift from the S. Mark Taper Foundation. 
A WALL OF TWO 



\section{A WALL OF TWO}

Poems of Resistance and Suffering from Kraków to Buchenwald and Beyond

H E N I A K A R M E L

A N D I L O NA KA R M E L

Introduction and Adaptations by Fanny Howe

Translated from the Polish

by Arie A. Galles and Warren Niesłuchowski

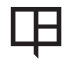

U N I V E R I T Y O F C A L IF OR N I P R E S

BERKELEY LOS ANGELES LONDON


University of California Press, one of the most distinguished university presses in the United States, enriches lives around the world by advancing scholarship in the humanities, social sciences, and natural sciences. Its activities are supported by the UC Press Foundation and by philanthropic contributions from individuals and institutions. For more information, visit www.ucpress.edu.

University of California Press

Berkeley and Los Angeles, California

University of California Press, Ltd.

London, England

(C) 2007 by The Regents of the University of California

For acknowledgments of permissions, please see page 119 .

Library of Congress Cataloging-in-Publication Data

Karmel-Wolfe, Henia.

[Poems. English. Selections]

A wall of two : poems of resistance and suffering from Kaków to Buchenwald and beyond / Henia Karmel and Ilona Karmel ; introduction and adaptations by Fanny Howe ; translated from the Polish by Arie Galles and Warren Niesluchowski.

p. $\quad \mathrm{cm}$.

Includes bibliographical references.

ISBN 978-0-520-25135-9 (cloth : alk. paper)

ISBN 978-0-520-25136-6 (pbk. : alk. paper)

1. Karmel-Wolfe, Henia-Translations into English. 2. Karmel, Ilona, 1925--Translations into English. 3. Holocaust, Jewish (1939-1945)-Poetry. I. Howe, Fanny.

II. Galles, Arie Alexander, 1944- III. Niesłuchowski, Warren. IV. Karmel, Ilona, 1925- Poems. English. Selections. V. Title.

PG7158.K286A2 2007

$891.8^{\prime}{ }^{17}-\mathrm{dc} 22$

2007015644

Manufactured in Canada

$\begin{array}{llllllllll}16 & 15 & 14 & 13 & 12 & 11 & 10 & 09 & 08 & 07\end{array}$

$\begin{array}{llllllllll}10 & 9 & 8 & 7 & 6 & 5 & 4 & 3 & 2 & 1\end{array}$

The paper used in this publication meets the minimum requirements of ANSI/NISO Z39.481992 (R 1997) (Permanence of Paper). 
Throughout the entire world, Rachel cries over her children, but they are not to be found. On the Hudson, the Thames, the Euphrates, Nile, Ganges, and the Jordan we blunder about in our confusion crying aloud: "Vistula! Vistula! Vistula! Our birth mother. Gray Vistula, river pink not from the rays of dawn, but rather from blood!"

J U L I A N U W I M 
